\title{
Performa Broiler yang Diberi Ransum Mengandung Daun Sengon (Albizzia falcataria) yang Direndam dengan Larutan Kapur Tohor $(\mathrm{CaO})$
}

\section{The Effect of the use of Sengon Leaves (Albizzia falcataria) Soaked in Kapur Tohor (CaO) on Broiler Performance}

\author{
Akmal dan Mairizal \\ Fakultas Peternakan Universitas Jambi \\ email: mairizal.mairizal@gmail.com \\ (Diterima: 25 November 2012 ;Disetujui: 20 Januari 2013)
}

\begin{abstract}
This research aims at meauring the use of Sengon leaves soaked in kapur tohor and it's effect on the performance of broiler. The Study used 100 broiler Hubber aged 3 days and 5 treatments ration which contain different Sengon. The design used in this study was completely randomized design (CRD) with 5 treatmen. Parameter measured were ration consumption, body weight gain, feed convertion and carcass. The result of this study shows that the use of sengon in the ration is effective significantly $(P<0.05)$ on the ration consumtion, body weight gain, carcass and feed convertion. It could be concluded that Sengon can be used up to $7.5 \%$ in the ration of the broiler.
\end{abstract}

Key Words : Kapur Tohor (CaO), Sengon, Carcass, body weight, feed consumption, convertion

\section{PENDAHULUAN}

Pakan merupakan faktor penting dalam keberhasilan suatu usaha peternakan dan harus dipenuhi untuk menjaga kelangsungan hidup ternak. Sebahagian besar bahan pakan masih bersaing dengan kebutuhan hidup manusia seperti jagung, tepung ikan dan kedelai sehingga harganya di pasaran juga mengalami peningkatan. Oleh sebab itu, perlu dilakukan usaha pemanfaatan bahan pakan alternatif yang mudah didapat dan tidak bersaing dengan kebutuhan manusia, seperti daun sengon.

Tanaman sengon (Albizzia falcataria) termasuk family mimosaceae, merupakan tanaman kayu yang dapat mencapai diameter besar. Tanaman sengon dapat tumbuh pada sebaran kondisi iklim apa saja, sehingga sengon dapat tumbuh dengan baik di berbagai tempat. Daun sengon berpotensi untuk dimanfaatkan sebagai pakan unggas karena memiliki kandungan nutrisi terutama protein yang cukup tinggi. Siahan (1999) menyatakan bahwa daun sengon mempunyai kandungan protein kasar 21,32\%, lemak kasar 10,09\%, serat kasar $14,72 \%$, Ca $0,21 \%$, P $0,35 \%$ dengan energi metabolis $3.056 \mathrm{Kkal} / \mathrm{kg}$.
Pemanfaatan daun sengon sebagai bahan pakan unggas terbatas oleh serat kasar, dan anti nutrisi tanin dan $\mathrm{HCN}$ yang bersifat racun bagi ternak (Mahyudin, 1983; Murdiati dan Mahyudin 1985; Brewbaket, 1986). Toruan (2001), melaporkan bahwa tepung daun sengon dapat digunakan sampai taraf 5\% dalam ransum broiler, pemakaian sampai $10 \%$ dapat menurunkan bobot badan dan hal ini diduga karena tingginya kandungan tanin sehingga menyebabkan terganggunya metabolisme tubuh ternak.

Tanin merupakan senyawa antinutrisi yang membentuk ikatan komplek proteintanin yang tidak larut air, mengakibatkan kekeruhan, pengendapan dan menghambat aktivitas enzim protease (Swain, 1965; dan Djuwadi, dkk., 1987). Tanin yang membentuk senyawa komplek dengan ikatan peptida dari protein, tidak larut dalam saluran pencernaan dan dikeluarkan melalui feses sehingga akan mempengaruhi ketersediaan protein makanan. Konsentrasi tannin yang tinggi dapat menyebabkan kelainan pada saluran pencernaan dan mengganggu mekanisme organ-organ pencernaan terutama hati, pankreas dan usus halus (Noor, 1992). Tanin juga dapat berikatan de- 
ngan berbagai mineral seperti mineral besi $(\mathrm{Fe})$ dan seng $(\mathrm{Zn})$. Tanin dalam jumlah besar dalam ransum dikawatirkan dapat menyebabkan defisiensi zat makanan seperti protein dan mineral. Salah satu cara untuk mengatasi hal tersebut adalah dengan merendam daun sengon dengan larutan kapur tohor atau $\mathrm{CaO}$.

Penggunaan $\mathrm{CaO}$ atau kapur tohor dalam rangka mengurangi kadar tanin didasari oleh adanya pengikatan senyawa tanin oleh ion $\mathrm{Ca}^{2+}$ sehingga membentuk garam tanat. Ion $\mathrm{Ca}^{2+}$ juga dapat meningkatkan aktivitas enzim tripsin dan khimotripsin yang berfungsi dalam pencernaan protein, di samping itu ion ini juga menyediakan mineral $\mathrm{Ca}$ dalam ransum. Amrullah dan Suryahadi (1992) menyatakan bahwa tanin dapat dihilangkan dengan perlakuan alkali misalnya dengan penambahan $\mathrm{NH} 4 \mathrm{OH}, \mathrm{NaOH}, \mathrm{K} 2 \mathrm{CO} 3$ atau kapur tohor $(\mathrm{CaO})$. Berdasarkan penelitian Wiryawan (1999) bahwa perendaman daun kaliandra dengan menggunakan larutan kapur tohor $(\mathrm{CaO}) 2 \%$ selama 30 menit mampu menurunkan kandungan tanin sebesar $48 \%$ serta dapat meningkatkan kecernaan protein 82,40\%, NDF (Neutral Detergen Fiber) 32,50 $\%$ dan ADF (Acid Detergent Fiber) 26,48\% secara in-vitro. Berdasarkan hal tersebut, telah dilakukan suatu penelitian untuk melihat pengaruh penggunaan daun sengon (Albizzia falcataria) yang direndam dengan larutan kapur tohor $(\mathrm{CaO})$ terhadap pertambahan bobot badan broiler.

\section{METODE}

Penelitian ini menggunakan 100 ekor anak ayam pedaging jantan umur 3 hari yang ditempatkan ke dalam kandang kawat berbentuk koloni berukuran 100x100x50 cm sebanyak 20 unit kandang dan setiap unit terdiri dari 5 ekor ayam yang dilengkapi dengan tempat pakan dan air minum serta alat penerangan dan pemanas ruangan berupa lampu pijar 5 Watt. Bahan makanan ternak terdiri dari daun sengon olahan, jagung, dedak halus, bungkil kedelai, tepung ikan, $\mathrm{CaCO} 3$, minyak kelapa, premix mineral dan bungkil kelapa. Di samping itu perlengkapan lain yang dibutuhkan yaitu obat-obatan untuk vaksinasi berupa Vaksin ND "Strain Lasota" dan penyakit lainnya antara lain obat pencegah stress berupa "Vita Chick." serta obat-obatan untuk mensucihamakan kandang yang digunakan yaitu "Rodalon".

Pengolahan daun sengon dilakukan sesuai petunjuk Wiryawan (1999) sebagai berikut: cara pembuatan larutan kapur tohor $2 \%$ yaitu dengan melarutkan kapur tohor sebanyak 30 gram dalam 1 liter air dan larutan ini digunakan untuk melarutkan 100 gram daun sengon selama 30 menit, kemudian dikeringkan dan dijemur sampai kering dan setelah kering digiling dan siap dijadikan campuran pakan.

Penelitian ini menggunakan Rancangan Acak Lengkap (RAL) dengan 5 macam ransum perlakuan yakni ransum yang mengandung $0 ; 2,5 ; 5 ; 7,5$ dan $10 \%$ daun sengon olahan di dalam ransum dengan 4 kali ulangan. Ransum perlakuan yang diberikan pada ayam percobaan selama penelitian adalah ransum yang disusun berdasarkan kebutuhan zat-zat makanan untuk ayam pedaging sesuai dengan NRC (1994). Kandungan zat makanan ransum perlakuan dapat dilihat pada Tabel 1 .

Tabel 1. Kandungan Zat Makanan Ransum Perlakuan

\begin{tabular}{llllll}
\hline Bahan Makanan & \multicolumn{5}{c}{ Ransum Perlakuan (\%) } \\
\cline { 2 - 6 } & \multicolumn{1}{c}{ R0 } & R1 & R2 & R3 & R4 \\
\hline Bahan Kering & 83,37 & 83,66 & 83,94 & 84,21 & 84,49 \\
Protein Kasar & 22,09 & 22,36 & 22,38 & 22,59 & 22,63 \\
Lemak Kasar & 5,42 & 5,59 & 5,63 & 5,66 & 5,74 \\
Serat Kasar & 6,17 & 6,64 & 6,94 & 7,27 & 7,62 \\
Calsium (Ca) & 1,41 & 1,42 & 1,44 & 1,46 & 1,48 \\
Phosfor (P) & 0,79 & 0,79 & 0,78 & 0,77 & 0,77 \\
EM (kkal/kg) & $2.968,84$ & $2.956,49$ & $2.965,64$ & $2.969,19$ & $2.973,04$ \\
\hline
\end{tabular}


Peubah yang diamati pada penelitian ini yaitu konsumsi ransum, pertambahan bobot badan, dan konversi ransum. Data dianalisis dengan menggunakan analisis ragam dan jika terdapat pengaruh yang nyata antar perlakuan maka dilanjutkan dengan uji jarak berganda Duncan (Steel dan Torrie, 1989).

\section{HASIL DAN PEMBAHASAN}

Rataan konsumsi ransum, pertambahan bobot badan dan konversi ransum selama penelitian dapat dilihat pada Tabel 2.

\section{Konsumsi Ransum}

Analisis ragam menunjukkan bahwa penggunaan daun sengon hasil rendaman dengan kapur tohor dalam ransum berpengaruh nyata $(\mathrm{P}<0,05)$ terhadap konsumsi ransum. Berdasarkan hasil uji jarak berganda Duncan menunjukkan bahwa konsumsi ransum pada perlakuan R4 lebih rendah $(\mathrm{P}<0,05)$ dibandingkan dengan ransum perlakuan R0, R1, dan R2, tetapi tidak berbeda dengan R3. Sedangkan ransum perlakuan R1, R2 dan R3 menunjukkan konsumsi ransum yang sama $(\mathrm{P}>0,05)$ dengan konsumsi ransum kontrol (R0).

Rendahnya konsumsi ransum pada perlakuan R4 disebabkan oleh meningkatnya kandungan serat kasar dalam ransum akibat dari peningkatan penggunaannya dalam ransum, sedangkan kandungan tanin diduga belum mempengaruhi konsumsi ransum karena kandungannya hanya $0,42 \%$ dan masih dalam batas toleransi ternak. Wiryawan (1999) me nyatakan bahwa perendaman daun kaliandra dengan larutan kapur tohor $2 \%$ selama 30 menit mampu mengurangi $48 \%$ kandungan tanin. Tingginya serat kasar pada perlakuan R4 (6,63\%) menyebabkan penurunan konsumsi ransum karena serat kasar bersifat bulky atau mengenyangkan sehingga kapasitas tembolok cepat penuh dan konsumsi ransum akan terhenti. Serat kasar yang tinggi menyebabkan unggas merasa kenyang, sehingga dapat menurunkan konsumsi karena serat kasar bersifat voluminous (Amrullah, 2003). Ransum yang tinggi kandungan serat kasarnya menyebabkan kurang palatable, sehingga menghasilkan konsumsi yang rendah (North dan Bell, 1990). NRC (1994) merekomendasikan bahwa sebaiknya serat kasar dalam ransum broiler tidak melebihi 6\%. Tillman dkk. (1984) menyatakan bahwa serat kasar akan mempengaruhi konsumsi ransum.

\section{Pertambahan Bobot Badan}

Berdasarkan hasil analisis ragam menunjukkan bahwa penggunaan daun sengon hasil rendaman dengan kapur tohor dalam ransum broiler berpengaruh nyata $(\mathrm{P}<0,05)$ terhadap pertambahan bobot badan. Hasil uji jarak berganda Duncan menunjukkan bahwa pertambahan bobot badan pada perlakuan R4 lebih rendah $(\mathrm{P}<0,05)$ dibandingkan dengan perlakuan R0, R1, R2 dan R3. Sedangkan perlakuan R1, R2 dan R3 menunjukan pertambahan bobot badan yang sama $(P>0,05)$ dengan kontrol (R0). Artinya, pemberian daun sengon olahan sampai taraf $7,5 \%$ dalam ransum tidak menunjukkan pengaruh terhadap bobot badan yang dihasilkan.

Tabel 2. Rataan Konsumsi Ransum, Pertambahan Bobot Badan, Konversi Ransum dan Bobot Karkas Broiler selama Penelitian

\begin{tabular}{ccccc}
\hline & $\begin{array}{c}\text { Konsumsi Ransum } \\
\text { (gram/ekor/hari) }\end{array}$ & $\begin{array}{c}\text { Pertambahan Bobot } \\
\text { Badan (gram/ekor/hari) }\end{array}$ & $\begin{array}{c}\text { Konversi } \\
\text { Ransum }\end{array}$ & $\begin{array}{c}\text { Bobot Karkas } \\
\text { (gram) }\end{array}$ \\
\hline R0 & $55,34^{\mathrm{a}}$ & $36,15^{\mathrm{a}}$ & $1,54^{\mathrm{a}}$ & $800,75^{\mathrm{a}}$ \\
R1 & $54,94^{\mathrm{a}}$ & $36,67^{\mathrm{a}}$ & $1,50^{\mathrm{a}}$ & $797,44^{\mathrm{a}}$ \\
R2 & $53,67^{\mathrm{a}}$ & $35,00^{\mathrm{a}}$ & $1,53^{\mathrm{a}}$ & $772,81^{\mathrm{a}}$ \\
R3 & $52,18^{\mathrm{ab}}$ & $32,92^{\mathrm{ab}}$ & $1,59^{\mathrm{a}}$ & $675,25^{\mathrm{b}}$ \\
R4 & $46,55^{\mathrm{b}}$ & $27,72^{\mathrm{b}}$ & $1,68^{\mathrm{a}}$ & $627^{\mathrm{b}}$ \\
\hline
\end{tabular}

Ket. : Angka-angka yang diikuti oleh huruf yang sama pada kolom yang sama menunjukkan tidak berbeda nyata $(\mathrm{P}>0,05)$ 
Penggunaan daun sengon hasil rendaman dengan kapur tohor dalam ransum sampai taraf $10 \%$ (R4) menunjukkan pertambahan bobot badan yang lebih rendah jika dibandingkan dengan R0, R1, R2 dan R3. Penurunan bobot badan berhubungan dengan rendahnya konsumsi ransum akibat tingginya kandungan serat kasar ransum. Serat kasar sulit dicerna di saluran pencernaan ternak unggas dan akan keluar bersama feses. Serat kasar bersifat melindungi zat makanan lainnya dari sistem pencernaan sehingga sebagian dari zat makanan tersebut akan keluar bersama feses. Akibatnya kebutuhan ternak akan zat-zat makanan untuk berproduksi tidak terpenuhi sehingga dapat menurunkan bobot badan. Wahju (1997) menyatakan bahwa selulosa merupakan serat kasar dan fraksi ini sulit dicerna oleh ternak unggas karena ternak ini tidak memiliki enzim selulase yang dapat menguraikannya.

Penurunan bobot badan pada R4 diduga bukan akibat pengaruh tanin, karena kandungan tanin dalam ransum perlakuan R4 0,42\% dan masih dalam batas toleransi ternak unggas. Menurut Fuller (1967) dalam Zain (1993) bahwa kandungan $1 \%$ tannin dalam ransum akan mempengaruhi pertumbuhan seekor ternak akan tetapi bila hanya $0,5 \%$ tidak mempengaruhi pertumbuhan. Tanin mempunyai sifat membentuk senyawa komplek dengan ikatan peptida dari protein, tidak larut dalam saluran pencernaan dan segera dikeluarkan melalui feses sehingga akan mempengaruhi ketersediaan protein dari makanan. Komplek tersebut tidak larut dalam air sehingga mengakibatkan kekeruhan, pengendapan dan menghambat aktifitas enzim sehingga mempengaruhi ketersediaan protein dari makanan (Djuwadi dkk., 1987). Tanin juga dapat berikatan dengan berbagai mineral termasuk mineral besi $(\mathrm{Fe})$ dan seng (Zn) sehingga jika terdapat dalam jumlah yang besar dalam ransum dapat mengganggu ketersediaan mineral tersebut.

\section{Konversi Ransum}

Hasil analisis ragam menunjukkan bahwa penggunaan daun sengon yang direndam dalam larutan kapur tohor menunjukkan pengaruh yang tidak nyata $(\mathrm{P}>0,05)$ terhadap konversi ransum. Penggunaan daun sengon olahan sampai taraf $10 \%$ menunjukkan konsumsi ransum yang lebih rendah dan diikuti juga oleh penurunan pertambahan bobot badan dari ransum kontrol (R0), demikian juga dengan perlakuan 2,5\% (R1), 5\%(R2) dan 7,5\% (R3) menunjukkan konsumsi ransum dan pertambahan bobot badan yang relatif sama dengan ransum kontrol sehingga tidak berbeda nyata. Artinya, kemampuan ternak untuk mengkonsumsi setiap gram ransum akan membentuk setiap gram daging yang sama. Siregar (1980) menyatakan bahwa konversi ransum sangat ditentukan oleh konsumsi ransum dan pertambahan bobot badan yang dihasilkan dan semakin baik mutu ransum maka angka konversi semakin kecil.

\section{Bobot Karkas}

Hasil analisis ragam menunjukan bahwa penggunaan daun sengon hasil rendaman dalam ransum berpengaruh nyata $(\mathrm{P}<0,05)$ terhadap bobot karkas ayam pedaging. Hasil uji jarak berganda Duncan menunjukan bahwa ransum perlakuan R3 dan R4 menghasilkan bobot karkas mutlak yang lebih rendah $(\mathrm{P}<0,05)$ jika dibandingkan dengan bobot karkas yang dihasilkan oleh ransum perlakuan R0, R1, dan R2. Sedangkan ransum perlakuan R1 dan R2 menunjukkan bobot karkas yang sama $(\mathrm{P}>0,05)$ dengan bobot karkas dihasilkan oleh ransum kontrol (R0).

Rendahnya bobot karkas pada perlakuan R3 dan R4 seiring dengan penurunan konsumsi ransum yang disebabkan oleh tingginya kandungan serat kasar ransum. Hal ini juga terlihat dari penurunan bobot badan pada perlakuan R3 dan R4. Serat kasar memiliki manfaat yaitu membantu gerak peristaltik usus, mencegah penggumpalan ransum, mempercepat laju digesta dan memacu perkembangan organ pencernaan (Amrullah, 2003). Serat kasar yang tidak dicerna akan membawa nutrien lain keluar bersama feses (Anggorodi, 1985) sehingga kebutuhan ternak akan zat-zat makanan untuk berproduksi tidak terpenuhi dan akhirnya akan menurunkan bobot karkas yang dihasilkan. 


\section{KESIMPULAN}

Tepung daun sengon (Albizzia falcataria) yang direndam dalam larutan kapur tohor $(\mathrm{CaO})$ dapat digunakan dalam ransum ayam pedaging jantan sampai taraf 7,5\%

\section{DAFTAR PUSTAKA}

Amrullah, I.K. dan Suryahadi. 1992. Kumpulan Bahan Penuntun Ilmu Makanan Ternak. PAU Ilmu Hayat Institut Pertanian Bogor.

Amrullah, I. K. 2003. Nutrisi Ayam Petelur. Lembaga Satu Gunung Budi, Bogor.

Anggorodi, R. 1985. Ilmu Makanan Ternak Unggas: Kemajuan Mutakhir. Universitas Indonesia Press, Jakarta.

Brewbaker, J.L. 1986. Legumenous trees and shrubs for southeast asia and the south pacific. In : Forage in Southeast Asia and South Pacific Agriculture. ACIAR Proc. No. 12:43

Djuwadi, H.I., B.S.L. Jenie dan A. Apriyanto. 1987. Kompleks protein-tanin; teori dan implikasinya dalam makanan. Media Teknologi Pangan. Vol 3 (34):47-56

Mahyudin, P. 1983. Nutritive Value of Tree Legumes Leaves. Research Report for 1983. BPT-Ciawi, Bogor.

Murdiati, T.B. and P. Mahyudin. 1985. The residual tannin and crude protein of Calliandra callothyrsus and Albizzia falcataria, following incubation in heated and unheated rumen fluid. In Efficient Animal Production for Asian Welfare. Proc. The 3 rd AAAP Animal Science Congress, Vol. 2 : 814-816.
National Research Council. 1994. Nutrient Requirement of Poultry. National Academy of Science, Washington.

North, M.D, and D.D. Bell, 1990. Commercial Chicken Production Manual. Second Edition. The Avi Publishing Co. Inc. Wesport, Conecticut. Noor, Z. 1992. Senyawa Anti Gizi. Pusat Antar Universitas - Pangan dan Gizi. Universitas Gadjah Mada. Yogyakarta.

Rasyaf, M. 1987. Beternak Ayam Pedaging. PT. Penebar Swadaya. Jakarta.

Siahaan, L.T. 1999. Pengaruh penggantian sebahagian bungkil kedelai dengan daun sengon (Albizzia falcataria) hasil fermentasi dalam ransum terhadap pertam bahan bobot badan puyuh. Skripsi. Fakultas Peternakan Universitas Jambi, Jambi.

Siregar, A.P., M. Sabrani dan S. Pranu. 1982. Teknik Beternak Ayam Pedaging di Indonesia. Margie Group, Jakarta.

Steel, R.G.D. and J.H. Torrie. 1989. Prinsip dan Prosedur Statistik.. PT Gramedia Pustaka Utama. Jakarta.

Sturkie, P.D. 1976. Avian Physiology. 3th. Ed. Springer Verlag, New York, Heidelberg, Berlin.

Swain, T. 1965. The Tannin in Plant Biochemistry. Academic Press New York : 552-558.

Taruan, P.L. 2001. Penggunaan tepung daun sengon (Albizzia falcataria) yang rendaman dalam ransum ayam pedaging. Skripsi. Fakultas Peternakan Universitas Jambi. Thomas, O and M.L. Scott. 1989. The value of methanol derived single cell protein for broiler. Poult. Sci $56: 266-273$. 
Wiryawan, K.G. Upaya pengurangan kadar tanin dalam daun kaliandra (Calliandra callothyrsus) dengan menggunakan larutan kapur tohor dan uji kecernaannya secara in-vitro. Med. Pet.. Vol. 22(2): 52-59.
Zain, B. 1993. Pengaruh berbagai tingkat kandungan tannin dalam ransum terhadap terhadap performan ayam pedaging. Tesis. Universitas Padjadjaran, Bandung. 